intent, which potentially could result in an infectious event. With the tuberculosis ventilation regulation, the $\mathrm{AI}$ are required to be evaluated before admission of a potential tuberculosis patient. There is not a regulation for PR. Continuous monitoring of SVRs is necessary to assure consistent airflow direction in critical patient-care environments. Hospitals should be designed to identify special ventilation needs with specification for ventilation control parameters. ${ }^{11}$ Without detailed SVR standards, especially for creating an airtight (sealed) room, ventilation control may be inconsistent.

\section{REFERENCES}

1. Ikeda RM, Birkhead GS, DiFerdinando GT Jr, Bornstein DL, Dooley SW, Kubica GP, et al. Nosocomial tuberculosis: an outbreak of a strain resistant to seven drugs. Infect Control Hosp Epidemiol 1995;16:152-159.

2. Fraser VJ, Johnson K, Primack J, Jones M, Medoff G, Dunagan WC. Evaluation of rooms with negative pressure ventilation used for respiratory isolation in seven midwestern hospitals. Infect Control Hosp Epidemiol 1993;14:623-628.

3. American Institute of Architects Academy of Architecture for Health and
USDHHS. Guidelines for minimum requirements for construction and equipment in hospitals. In: Guidelines for Design and Construction of Hospital and Health Care Facilities, 1996-1997. Washington, DC: AIA Press; 1996.

4. Murray WA, Streifel AJ, O'Dea TJ, Rhame FS. Ventilation for protection of immune compromised patients. ASHRAE Transactions 1988;94:1185-1192.

5. Guidelines for preventing the transmission of Mycobacterium tuberculosis in health-care facilities, 1994-CDC. Notice of final revisions to the "Guidelines for Preventing the Transmission of Mycobacterium tuberculosis in health-care facilities, 1994." Fed Regist 1994;59:54242-54303.

6. First MW. Ventilation for biomedical research, biotechnology, and diagnostic facilities. In: Liberman DF, Gordon JG, eds. Biohazards Management Handbook. New York, NY: Marcel Dekker, Inc; 1989:45-72.

7. Nicas M, Sprinson JE, Royce SE, Harrison RJ, Macher JM. Isolation rooms for tuberculosis control. Infect Control Hosp Epidemiol $1993 ; 14: 619-622$.

8. Hitchings DT. Laboratory Space Pressurization Control Systems. ASHRAE Journal 1994;362:36-40.

9. Rousseau CP, Rhodes WW. HVAC system provisions to minimize the spread of tuberculosis bacteria. ASHRAE Transactions 1993;99:12011204.

10. National Fire Protection Association. Life Safety Code 101. Quincy, MA: NFPA; 1997.

11. Streifel AJ, Marshall JW. Parameters for ventilation controlled environments in hospitals. In: Design, Construction, and Operation of Healthy Buildings. LAQ 97. Bethesda, MD: ASHRAE Press; 1998.

\title{
Chile Establishes Law to Control Antibiotic Use
}

\section{Jaime Labarca}

Antibiotics commonly are sold over the counter in Latin American countries. Bavestrello and colleagues from Hospital Dr. Gustavo Fricke, Viña del Mar, Chile, recently studied antimicrobial use and related costs in Chile and reported on how these data were used to implement a governmental policy mandated on prescriptions. Using antibiotic sales in Chile, per year, either in grams of antibiotics or in sale units, they reported a significant increase in the daily defined dose (DDD) per 1,000 person-days. From January 1997 to December 1998, they reported a $498 \%$ increase in amoxicillin, $309 \%$ increase in oral cephalosporin, and a $473 \%$ increase in oral fluoroquinolones. Chloramphenicol was the only antibiotic that decreased (18\%) during this period.

$$
\text { A number of groups, including the }
$$

Chilean Scientific Societies, Ministry of
Health, National Health Institute, and the Health Commission of Congress, met to review these data. It was agreed that a law requiring medical prescriptions for antibiotics was needed. Since it was anticipated that the law would be unpopular, a national educational campaign to rally public support was developed with assistance from the Chilean College of Physicians, the Chilean College Pharmacists, and the National Consumer Services.

One year after the intervention, a second study was done to evaluate the change in consumer behavior and trends in consumption of antibiotics. This second study compared the use of antibiotics in two trimesters, during the same calendar months, the first one before and the second one after the intervention. (OctoberDecember 1998 vs the same period in 1999). The consumption and sale of amoxicillin decreased $36 \%$, ampicillin $56 \%$, and erythromycin $30 \%$. This change resulted in a $\$ 6.4$ million (US) savings for the period of 1998 to 1999.

The studies show how scientific data can be used to influence governmental policy to optimize antibiotic use and to help prevent antimicrobial resistance. A collaborative effort among scientific societies and the government contributed to the success of this program. The researchers note that Chile is the first Latin American country to establish mandatory medical prescription for controlling antibiotic use in the outpatient setting.

FROM: Bavestrello L, Cabello A. (1) First evaluation of the impact of the regulatory measures on antibiotic use in the outpatient setting in Chile. (2) Trends of use of antibiotics in Chile in the last 10 years. Presented at the XVII Annual Conference of the Chilean Infectious Diseases Society; August 2000; Viña del Mar, Chile. 